\title{
DĪPAMKARA IN THE TANGUT CONTEXT: AN INQUIRY INTO THE SYSTEMATIC NATURE OF TIBETAN BUDDHISM IN XIXIA
}

\author{
$($ PART 2)
}

\author{
KIRILL SOLONIN \\ Renmin University of China, Institute of Chinese Classics \\ Beijing, Haidian, Zhongguan cun dajie, 59, 100872, China \\ e-mail: kirill_solonin@mail.ru
}

In the previous part of this paper attempt has been made to reconstruct the Tangut Buddhist context in which the works of Atiśa emerged in the Tangut State during the 12th and early 13th centuries. The following part is directly dealing with currently identified texts attributed to Dīpaṃkaraśrijñāna available in the Tangut versions.

Key words: Tangut Buddhism, Tibetan Buddhism, Bka' brgyud, Bka' gdams, Atiśa, doctrinal Buddhism.

\section{Dīpamkaraśrijñāna in the Tangut Sources}

Generally, in the Xixia texts known to me, either in Chinese or in Tangut, the name Atiśa appears only once, whereas the name Dīpaṃkara (閏綿蟒貍 "tśhjiw pja kjaa rjar, i.e. *Tshipakara) emerges often. In the following, I attempt to position Atiśa against the background of Tibetan Buddhism in the Tangut State as it was partially presented earlier.

The entry on Dīpaṃkara from "The Praise for the Eighty Five Mahāsiddhas" reads as follows:

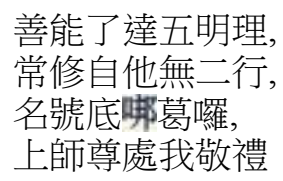

${ }^{*}$ Continuation of Kirill Solonin's Dīpamkara in the Tangut Context: an Inquiry into the Systematic Nature of Tibetan Buddhism in Xixia (Part 1). $A O H$ 68, No. 4, pp. 425-451. 
Rig pa'i gnas lnga mkhyen pas brgyan/ bdag gshan gnyis su med par mdzad/

Mar me mdzad ces bya ba'i/

bla ma de la phyag 'tshal lo ${ }^{1}$

The one who attained the knowledge of the Five vidyas;

Always practising non-duality of oneself and the other;

The one whose name is "Dīpamkara (i.e. Maker of the Lamp)";

To this revered lama I offer my homage.

The esoteric connection of Atiśa in Xixia is illustrated with Dīpamkara's entry in the Tangut fragment \#2885, mentioned previously. The encounter with Atiśa (or rather with his symbolic representations) is preceded by the attainment of the luminous mind, which is described in the text in the following manner:

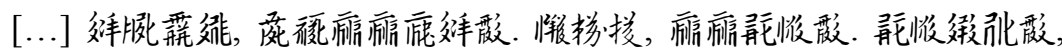

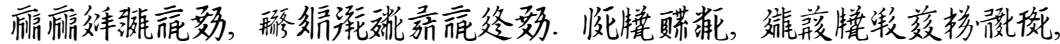

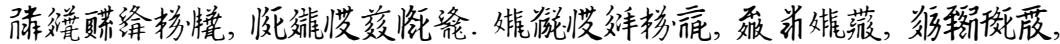

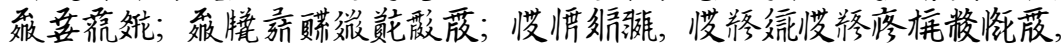

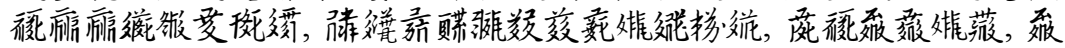

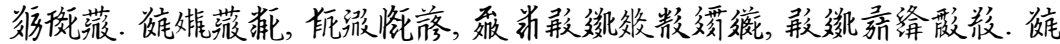

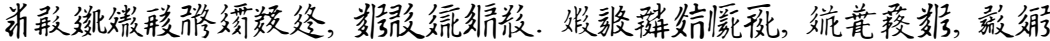

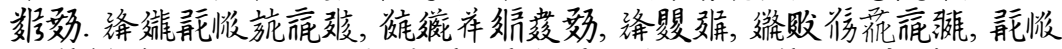

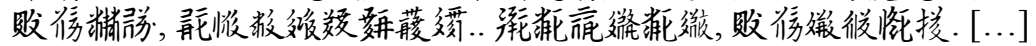

[Tentative translation] [...] I have attained the nature of mind; cut off the doubts, [since they] are the deluded wisdom (娟惔, 妄知). It is said: the deluded wisdom is impermanent, ${ }^{2}$ and all arise from the mind"; [it is said] "without efforts [the nature of mind] thus arises by itself".

Again, from the perspective of the essence of consciousness (here used, analogue of Sinitic 識, vijñāna), is similar to the meeting an old friend, it is the true realisation of the substance of original enlightenment (䠈䵊䤀, 本覺體). Again, this [contemplation] will be different from the contemplations [which one had] before. As soon as the mind

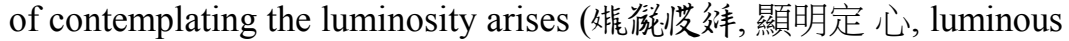
mind in the state of samādhi), sometimes it manifests itself and is seen as an art of illusion, sometimes [the mind] is seen as reality; sometimes [one] sees the self-nature of consciousness as permanently alone, and since there will be nothing but contemplation, [one] will not see the duality (lit. "two types") between the object of contemplation and the one who contemplates; and there will be clear understanding that all the dharmas have become as the outer skin, departed from the self-sub-

${ }^{1}$ HanZang Fojiao guanxin shiliao ji, p. 56 (祝5).

${ }^{2}$ Tangut $r j$ ir bow 傩张 literally translates as “quickly disappear”, however, the meaning of the word remains obscure. The sentence is concluded by the verb "to be", thus verbal translation of rj ir bow is not plausible. 
stance of the original enlightenment. [Then] all the dharmas would sometimes appear as empty, sometimes as an illusion. In this understanding

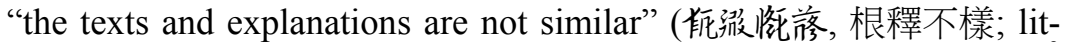
eral translation); the understanding (搌效, 智受) will be wide and broad”3 and will be true by itself. Despite this understanding being strong and solid, it cannot increase. Later in the Land of "*Increasing Moon" (lhow

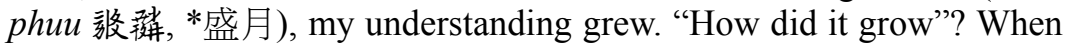
the deluded wisdom arose, it [appeared] to have no effect and [I] was truly joyful. Now, when the light arises, the deluded wisdom enters into the light, [which] can no longer be obstructed by the deluded wisdom. From that time and until today, the light continues and never interrupts.

The following encounter with Dīpamkara is represented as another in the series of the dream experiences. The text invites further study, and my interpretation of it is far from flawless. The context where Dipamkara emerges is as follows (tentative translation):

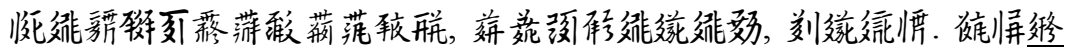

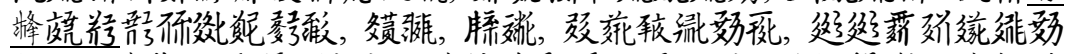

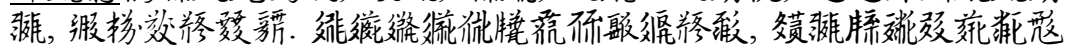

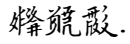

Then again, I dreamt that I obtained a golden box and a lacquer basket, and one of [my] companions said to me: "I will look at it, do not look [there] alone. Here are the bones and śarīra of the teacher Dippamkara ${ }^{4}$

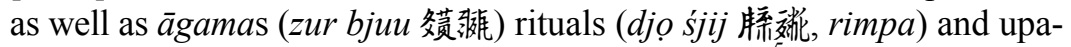

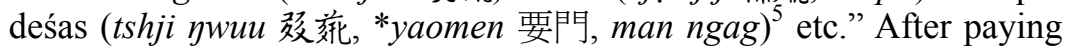
homage many times, I said "I will look".

"Then I had a dream that an oral explanation was done [for me]." [This is] the auspicious sign (lja·jij 㛆韽, *ruixiang 瑞相) that now I can benefit many sentient beings and rely on the agamas, rituals and upadeśas. [...]

One can infer that the dreaming about the śarīra of Dippamkara was the first in the series of dream encounters of the author of \#2885. These encounters culminated in his attainment of the Six Yogas and Tilopa's teaching of the nature of mind, which is the overall focus of the text. The text clearly views Atiśa as the founding master in

${ }^{3}$ Here Tangut 熫 is used, indicative of the general topic of the utterance. There is a possibility that the saying in brackets is a quotation from another text, yet to be identified.

${ }^{4}$ This is a particularly interesting note, since the Blue Annals inform that there were no relics left after Dīpamkara's cremation.

${ }^{5}$ zur 呅, ${ }^{*}$ shengjiao 聖教 as used in Dacheng Yaodao miji, Tib. lung. See the note in Blue Annals, where Milarepa complains to Gampopa that Kadampas do not have man ngag (upadeśas; The Book of Kadam: Core Texts. Translated by Thupten Jinpa, New York, Wisdom Publications 2008), Introduction, p. 5). This part of the sentence might be translated as "upadeśas for the practice according to āgamas". 
the lineage of the teaching of the "nature of mind" and Mahāmudrā, the source of the oral instructions (upadeśa) as well as of the doctrinal learning (āgama) and ritual manuals (krama, vidhi). Further in the text, the author laments that today is not as it was before: yogis have passed and there are no instructions and no one to guide through the intermediate existence. So where can one meet the Masters of old, if not in a dream?

From the paragraph quoted above one can infer that at least the author of \#2885 located Dippamkara within the lineage of Milarepa, Marpa, Lhazhe, Yarlungs pa and other figures mentioned in the composition. If my interpretation of the above paragraph is correct, through Dīpamkara's "teachings" one can approach esoteric perfections, epitomised further in the text as Tilopa's understanding of the nature of mind; this places Dīpamkara within esoteric context of Tangut Buddhism dominated by Bka' rgyud agenda.

Historical biographies of Atiśa available in Tangut are generally in tune with the traditional Tibetan accounts: in general the available Tangut texts represent Atiśa as the abbot of Vikramaśîla who expelled a yogic practitioner (Maitrīpa's name does not emerge in the Tangut context) from the monastery for using wine in the Vajravārāhī rituals. Following the instructions of his titular deity Tārā, Atiśa then had to travel to Tibet in order to remove the karmic obstacles for the attainment of Mahāmudrā. This story is presented in a text which is directly attributed to Dīpamkara: the so-called Upadeśa of the Forty Banners of Emptiness (lj i ir ra ma ya dźjow tshji

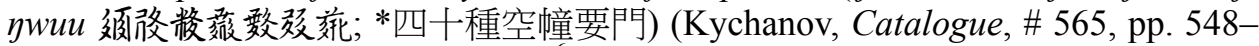
549, call number Tang 215, \#871). ${ }^{6}$ From the linguistic perspective, this text is clearly a translation from Tibetan; however, its original is not yet identified. The introduction to the texts mentions that Dīpamkara composed this work on the basis of all tantras and upadeśas which he deemed appropriate for the Tibetans who had abandoned the true path of Mahāyāna. This text will be discussed in more detail below, for the moment it will suffice to mention its transmission lineage in Tibet. The text reads as follows:

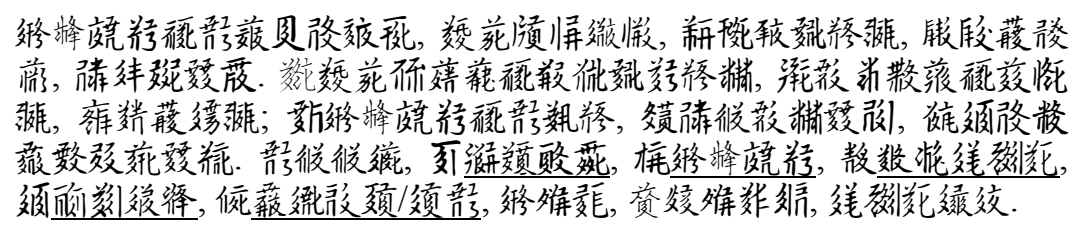

[Tentative translation]: The Dharma protector master Dīpamkara [passed] eighty women (i.e. d̦ākin̄is), and arrived in the Bod country; through repentance [he] purified karmic obstacles, and saw the face of tutelary deity (lit. "the original Buddha"). pamkara."

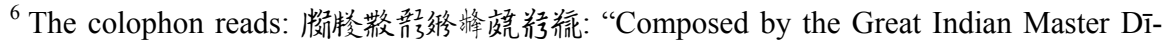


Afterwards, among many of the Dharma gates of the Secret collection, which were explained in Tibet, many did not follow the teaching of Mahāyāna and were overly lax; thus Dīpamkara collected from the sacred instructions (i.e. āgamas) and tantras and composed this Upadeśa [known as] The Forty Banners of Emptiness. The lineage of teachers: Mother

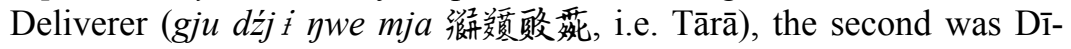
pamkara, the third was Lotsāwa "Precious Parasol (ljibju lu tśja wa

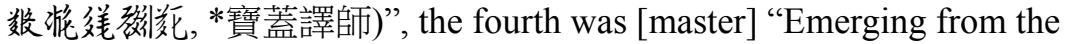
Conqueror” (buu swie to mjii? 劤刻㣪烽, *勝勢出施 $=$ Rgyal ba 'Byung gnas), the fifth was dhāran̄i master Bero (bororsj itow / lhjij 鞯

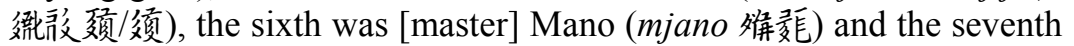
were lama Skye med (ljamja weemji 效倠效缅) and Lotsāwa Sumpa (绿挍).

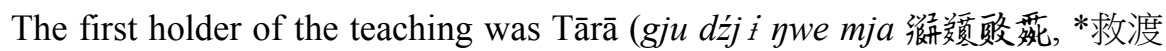
天母), Atiśa's tutelary deity; the second was Dipamkara himself. The third person who received the teaching was lotsāwa "Precious Parasol" who can be provisionally identified as lotsāwa Rin chen Bzang po (958-1055; lj ibju lu tśja wa 数湤绕绞浐, *寶蓋譯師, “Precious Parasol”, Rin chen gdugs), with whom Atiśa had a lengthy intercourse upon arriving to Tibet; the fourth was *Dromton ('Brom ston, 1005-1064; buu swie to mjii? 胕刻㣪㖓, *勝勢出施, “Emerging from the Conqueror” Rgyal ba' $i$ 'byung gnas); the fifth was lama *Berośri (*Berosita/ Berosili; barorsj itow/ lhjij 茂

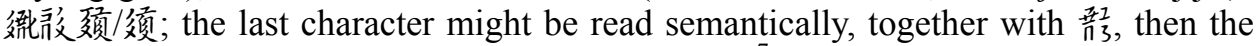
composite word translate as the "dhāran̄i master"), ${ }^{7}$ the sixth was *Mano (mjano 晦 爱, “"Joyful in the East”); the seventh recepient includes the Lama "Unborn" (Skye med) (lama weemji 发麦䄯效绖, *辣麻無生, Wusheng, whom we tend to identify with famous Tangut translator Dehui) and lotsāwa *Sumpa 䘨效 (possibly Lama Sumpa Sangs rgyas), ${ }^{8}$ who probably is identical with lama Sumpa (松巴) from the Vajravārāhī lineage (part 1).

${ }^{7}$ One might be inclined to read the first two syllables as the transcription Bero (as in Berotsana/ Vairocana). However, the name of Berotsana in Tangut is written as Bero 收姘, which makes identification doubtful. See discussion above.

${ }^{8}$ Two Tangut characters used in the "Banners of Emptiness" and "Oral Transmission" represent different phonetic values: 㸼 is used to render "ba" whereas 佼 (occurs in "Forty Banners") transmits " $\mathrm{ph} / \mathrm{bo}$ ", given the uncertainty of the Tangut rules of transcription, I temporarily believe them to represent close phonetic values.

${ }^{9}$ Among the five masters following Atîśa, only Rin chen Bzang po can be identified with a degree of certainty: Tangut 数 normally translates Chinese bao 寶, and is thus equivalent of the Tibetan “rin chen”. The second Tangut character reads as Chinese $f u$ 覆 or gai 蓋 (“to cover”, “to be on top") and thus can be rendered as a derivative from "bzang po" ("lovely", "good", "excellent") etc. As for Dromton, my identification is purely hypothetical. The reasons are as follows: Tangut 耐铜 can be rendered as Chinese “shengshi 勝勢” “victorious power" (such usage is attested in “Sizi kongxingmu jiwen” 四字空行母記文, where 勝勢 is epithet of Maitrīpa; however, “The Golden Garland of Mahāmudrā" uses "shengshi 勝勢” to translate mi-pham, "unsurpassable") which can be taken as a partial synonym for "rgyal ba" (victorious), while 㣪㖓 might be translated as "chushi 出施” ("to give away"). Provisionally I translate the name as "emerging from the 
If correct, the final transmission of $B k a^{\prime}$ gdams teaching in Xixia occurred through the mediation of the similar people who transmitted both Mahāmudrā and Vajravārāhī teachings. The general context of the aforementioned compilations allows connecting Atiśa with the most important lineages of transmission of Tibetan esoteric Buddhism in the Tangut state, including Wusheng, Lhazhe and Lama Sumpa. It also brings together the systems of Bka' gdams, Mahāmudrā and Vajravārāhī as the core traditions of Tibetan Buddhism in Xixia, and actually makes Atiśa a crucial figure in the formation of the Tibetan Buddhist complex in the Tangut state.

\section{Dīpaṃkara Texts in the Khara-Khoto Collection}

Satyadvayāvatāra. Although a substantial part of the Khara-Khoto collection remains uncatalogued, the entries listed in Kychanov's Catalogue allow an insight into the popularity of the works of Atiśa and texts associated with his teaching in the Tangut Empire. Kychanov lists the following texts whose titles or colophons imply a rela-

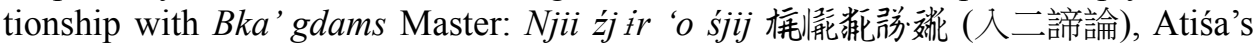
famous Satyadvayāvatāra, Bden ba gnyis la 'jug pa. According to Kychanov, the entry Tang 197 contains the following inventory items: 864, 865, 866, 867, 868, and 869 which are scroll manuscripts, which Kychanov divides into parts 1, 2 and 3. Entry Tang 296 contains one item (inventory 2531) which is a butterfly (hudie 蝴蝶) type booklet (Catalogue, pp. 495-496; \#\# 405-408). While preparing this study I was only able to examine items \#865, 866, 868, 869; 2531 was beyond my scrutiny.

Another fragment of Atiśa's work is found in a manuscript "convolume" containing several compositions, Tang 296 \#2531, with the standard "butterfly binding". The Entry into the Two Truths is the opening work in the collection; the text survives with an opening colophon that clearly indicates its title and authorship. The extant part is damaged, but luckily it preserves the initial part of Atiśa's opus which is not found in Tang 197. In Tang 296, Atiśa's work is found on pages one through eighteen in the modern pagination, and the following twenty-one pages contain a short doctrinal treatise identified as a topical exposition of the Nyāyabinduprakarāna, opening lines, and title of a ritual manual on "offering food and water". A preliminary study indicates that despite the overall similarity, the two versions of the Satyadvayāvatāra represent different versions of the text: the deviations between the two texts cannot be explained, only by the scribal errors.

The photographs available to me demonstrate that inventory entries 865 and 866 are in fact one and the same text, which for some reason is mentioned and catalogued twice. The available text begins with Tangut: “" $\square$ tśja bja thjuu lew mjij,

Conqueror', one of the 'Brom ston names ('Brom ston Rgyal ba'i 'byung gnas) in the Blue Annals. (I refer to the Russian edition of the Blue Annals: Гой лоцзава Шоннупэл ['Gos lo ta ba gZhon nu dpal], Голубые Анналь [Blue annals], (St. Petersburg, Eurasia Press, 2001, p. 155.) The last Tangut character in the name is not clearly legible. As for the fifth and sixth masters, I cannot come up with a plausible identification. The fifth might be provisionally reconstructed as Vajrasila or Vajrasri. 


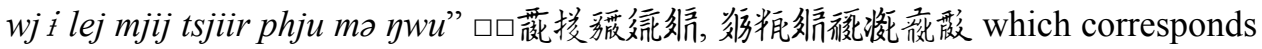
to original Tibetan: “...brjod du med pa bltar med pa/ 'gyur ba med pa 'dus ma byas/". The concluding colophon to the Tangut translation mentions only the title of the text, but neither date of translation, nor the name of translator is provided. The available Tangut text is probably based on a standard version: during revision, the scribe realised that he omitted one line, and had to add it as a superscript. Apart from some inconsistency in the final part of the text, where Atiśa discusses the composition of his work in Suvarnadvippa, the Tangut translation is loyal to the Tibetan original. Only few examples of deviation from the meaning of the original have been identified so far, and these can be explained as natural deviations in the process of translation, rather than lack of understanding. ${ }^{10}$

\section{Commentaries to the Satyadvayāvatāra}

The following list is not exhaustive, since the new versions of commentaries to the Entry into the Two Truths continue to emerge with the growth of scholarly familiarity with the Tangut textual corpus. What follows below is a brief exposition of the texts which share definite subject matter affiliation with the Dippamkara's treatise.

1. Item 868 is not the actual text of the Tangut translation of Bden ba gnyis la ’jug pa but a commentary to Atiśa's composition, titled Njii źj ir 'o śjij la phju?

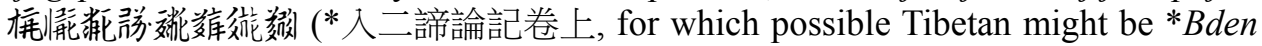
ba gnyis la 'jug pa'i bkral or bkral 'grel). The preserved part of the text contains 179 lines, 20 characters per line, which makes it a lengthy composition. The colophon is concluded with an editorial remark: njar lew 㦈能, “revised, [the text is] correct".

2. Item \#869 bears no clearly identifiable title, but again is a commentary to Bden ba gnyis la 'jugs pa followed by a dhāran̄ī text added by a different scribe. A portion of the text consisting of about 300 lines, each containing approximately 20 characters is available now.

3. Apart from the above, Kychanov's Catalogue mentions another text, Tang 498, \#833, which is another commentary to Bden ba gnyis la 'jugs pa. The title of the text is "Explanation of the Meaning of the Treatise on the Entry into the Two Truths",

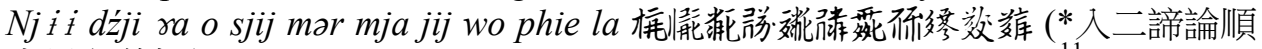
本母之義解記, *Bden ba gnyis la 'jugs pa'i bstan bcos kyi don gsal). ${ }^{11}$ The author

${ }^{10}$ Dr. Liu Guowei 劉國威 from the National Palace Museum and I are currently involved in a thorough study of the Tangut translation of Bden ba gnyis la 'jugs pa, therefore, this text will be discussed here no further.

${ }^{11}$ The form in which Atiśa's work is mentioned in the title of the composition by Byang chub sengge is probably the correct version of the title: Tangut mar mja 跘舞 translates Sinitic benmu 本母, "śastra". This term occurs frequently in the translation of the Chinese doctrinal writ-

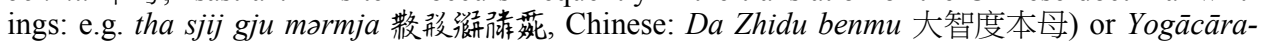

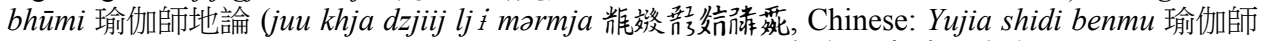

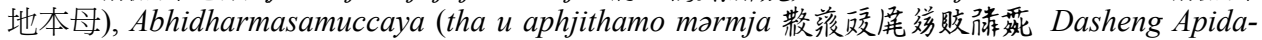
mo jilun 大乘阿毘達磨集論). Tangut sjij 玈, as was demonstrated by Duan Yuquan (段玉泉), 
of this commentary is Potj ij katśjij 效效釉昸 (*菩提獅子, *Byang chub seng ge). The text contains colophon which indicates that copying of the one juan of the text was "completed on the 15th day of the third month of the dog year of the Heavenly Assistance reign period", i.e. 5th of April, 1178 (Catalogue, p. 568, \#619).

4. Catalogue lists a text with a title ywe lu tśja wa tschjii tj ij lwu źj ir wo la

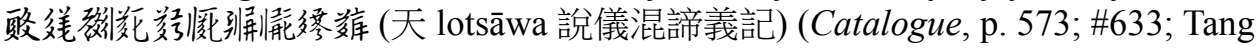
367, \#4732). The surviving part of the manuscript contains about four hundred lines with approximately 20 characters per line. The scroll has long before been dismantled, so the sequence of the surviving parts is hard to determine. In my understanding, the Catalogue has mistaken the character njii 㭠 (two) for $t j i j$ 洲 (混, 融) and read $\eta w e$ as a meaningful word instead of transcription. In fact the Chinese calque of the actual title should read as *俄譯師說儀二諦義記, “Exposition of the meaning of the Two Truths according to E lotsāwa" (*Nge lotsāwa lugs kyi bden gnyis kyi don 'grel). Identity of "Nge (E) lotsāwa" is relatively easy to establish: Kozlov collection contains another scroll "*Laudation to Abhisamayālamkāra elucidating the meaning

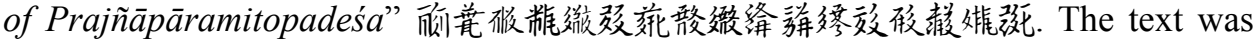
originally identified by Nishida Tatsuo as Shes rab kyi pha rol tu phyin pa'i man ngag gi bstan bcos mngon par rtogs pa'i rgyan ces bya ba'i 'grel pa (Abhisamayālamkāranāmaprajñāpāramitopadeśa śāstra vritti). ${ }^{12}$ The Tangut edition is provided with a lengthy colophon indicative of high esteem in which this text was held in Xixia. Among others, the colophon mentions that the one of the authors of the new Tibetan

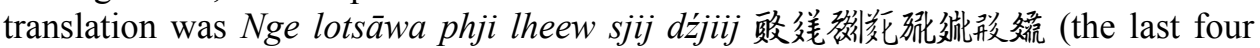
characters read *有意有智), which translates back into Tibetan as "Blo ldan Shes rab", 13 otherwise known as Rngog lotsāwa. Considering the phonetic value of "rngog" as "og", and the dropping of the final consonant "-g" in Tangut, one can identify Tangut “婹” as the transcription of the Tibetan "og”. By this token, the person in question will be Rngog lo tsā ba Blo ldan Shes rab (1059-1105), famous translator associated with Atiśa, ${ }^{14}$ whose texts have been discovered in Khara-Khoto. The final part of the Tangut text reads as follows:

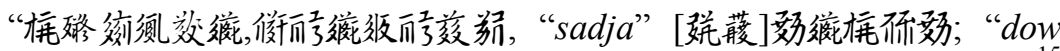

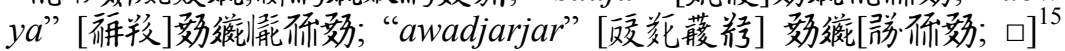

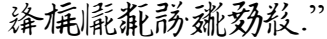

"The second, explanation of the name, [it is in] Sanskrit, similar [meaning] in the language of Mi (Tangut) is: the word "sadja (satya)" is the word for "two" (sic!); the word "dow ya" (dvaya) is the word for "truth";

indicates that the preceding verb should be understood as a noun, thus turning Tangut $o$ 颜 (to enter) into a noun: "entrance". On other occasions the abridged version of the title is used.

${ }^{12}$ Catalogue, pp. 490-493, Tang 101, \#\#5130, 4722, 5179, 5164, 2888, 8329, 6449; \#5191 in the Catalogue of Beijing edition of $B k a$ ' 'gyur.

${ }^{13}$ For similar considerations see in Nie Hongyin, “Tubo jingshi Xixia yiming kao” 吐蕃經 師西夏譯名考 in: Xixia wenxian lungao, pp. 257-258.

${ }^{14}$ For example, Blue Annals, p. 186.

${ }^{15}$ Damaged text, my reconstruction. 
the word "awadjarjar (avatara) is the word for "entrance"; [it would] then mean "Entry into the Two Truths".,"16

Apart from the interesting interpretation of the Sanskrit title, the colophon surely states that this is one of Rngog Lo's commentaries on Satyadvayāvatāra. The exact title of the text has not survived, and more research into the text is necessary. ${ }^{17}$ That is, currently, apart from the actual translation of Satyadvayāvatara, the Tangut collection contains four commentaries to Atiśa's famous work, which makes Bka' gdams literature an important factor in the agenda of Tibetan Buddhism in the Tangut State.

5. Upadeśa of the Forty Banners of Emptiness (lj i ir ra ma ya dźjow tshji

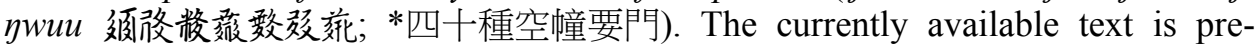
served in full; it is a scroll containing 280 lines, about 20 characters per line. The text consists of forty smaller entries, some of them titled "upadeśa", whereas others are introduced by numbers only. Some entries in the text are numbered in Chinese. Neither opening nor concluding colophon contains information on the person, date and time of translation.

\section{Origin of the Texts}

The colophons of Atiśa's works and texts associated with him are not informative, and generally mention only the title of the text. The one exception is "Explanation of the Meaning of the Treatise on the Entry into the Two Truths" by *Byang chub seng ge. Although this is a popular name and there is no reason to doubt the reconstruction of its original Tibetan form, as of now I cannot come with a plausible identification of this person. The colophon of the text is preserved in full, and reads that "copying of the text was completed on the 15th day of the third month of the dog year of Heavenly Assistance (敋展, 乾祐, 03. 04. 1178) reign period” (Catalogue, pp. 567-568, \#619).

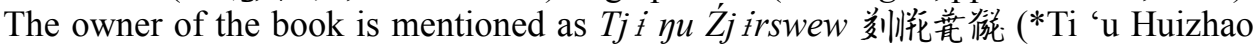
慧照). Although the family name * $\mathrm{Ti}$ ' $\mathrm{u}$ is not attested in the available Tangut texts, the monastic name Huizhao emerges several times in the translations of both esoteric and exoteric texts.

1. "*Laudation to Abhisamayālamkāra elucidating the meaning of Prajñāpāramitopadeśa" colophon mentions that one of the Tangut

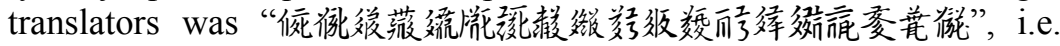

\footnotetext{
${ }^{16}$ Kano in his list of Rngog lotsāwa's works mentions only Bden chung [gi] bsdus don Kano (2008, p. 130). Kano provides no publication data on this text, so it remains unavailable to me.

${ }^{17}$ The reason for such an explanation of the title was that the translator directly reversed the word order of the Tibetan original: i.e. bden gnyis "truths two" in Tibetan. In Tangut numbers in standard combinations ("three worlds", "five skandhas") can be put before the noun, according to the Chinese pattern. The translator further assumed that the original Sanskrit order of words in Buddhist terms would be the same with Tangut and Chinese, while in this particular case it was similar to Tibetan. Thus the Tangut translator reversed Tibetan believing that he is thus reproducing original Sanskrit.
} 
"The expounder of sūtras, śāstras and vinaya, expert in Bod (Tibetan) and Mi (Tangut) languages from The Monastery of Manifestation of the Five Wisdoms, dge slong Li Huizhao".

2. Ärya Vajracchedikānāmaprajñāpāramitāmahāyānasūtra (亥商

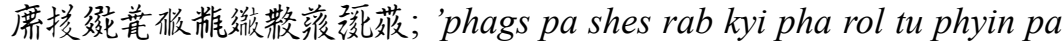
rdo rje gcod pa shes bya ba theg pa chen po'i mdo; 圣般若波羅蜜 多能斷金剛大乘經) (Catalogue, p. 484, \#380, Tang 81, \#2561, Beijing Bka' 'gyur \#739). According to the colophon, the text was "collected" by "reverend *Supia 绿数裉微” and translated by Huizhao. At the mo-

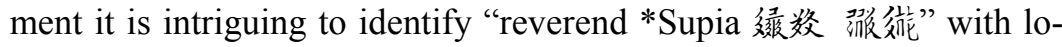
tsāwa *Sumpa 绿交, mentioned as one of the holders of Atiśa's teaching of the "Forty Banners of Emptiness" and the one mentioned in the Oral Transmission.

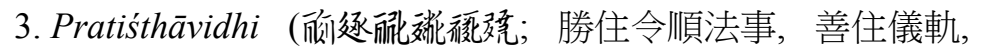
Rab tu gnas pa'i choga), composed by Sumatikīti and translated into Tibetan by Prajñākirti (Catalogue, p. 490, \#391, Tang 97, \#810).

4. "Precious Torch Elucidating the Bodhisattva study of Fruit as

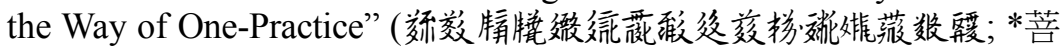
提勇識所學道及果與一順顯明寶炬), which was most probably composed by Gtsang po pa Dkon mchog sengge (?-1219), Dus gsum mkhyen pa's disciple sent over to Xixia. Apart from this, Huizhao translated a text on attaining longevity and a group of texts associated with the Six Yogas of Nāropa. These texts include:

5. "Upadeśa commanding attainment of union between desire and

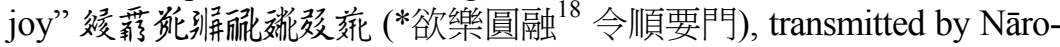
pa and translated by Huizhao or copied probably in the 1220s in The Monastery of Manifestation of the Five Wisdoms (Catalogue, pp. 558-559, \#594). ${ }^{19}$ The available version of this text consists of several shorter verse treatises devoted to the Six Yogas subject matter, partially coinciding with the aforementioned collection of texts by Chos kyi seng ge. ${ }^{20}$

${ }^{18}$ A lot of Tangut texts of Tibetan subject matter use the term equivalent of Sinitic "yuanrong" 圓融 in both titles and body text. As of now, I cannot think of Tibetan equivalent: terms otherwise translated as union such as "kha sbyar" or "mnyam sbyor" have their established equivalents in Tangut not traceable to "yuanrong".

${ }^{19}$ Kychanov mentions the date of copying another copy of the text as 1223 , but admits that the colophon is illegible. I was not able to examine this particular copy.

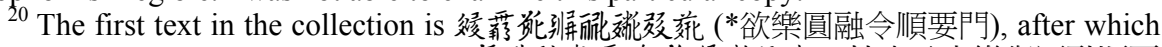

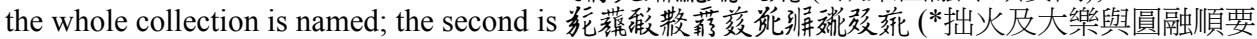
門; “Upadeśa for attaining unity of the Great Joy and Inner Heat”); this text includes indication of

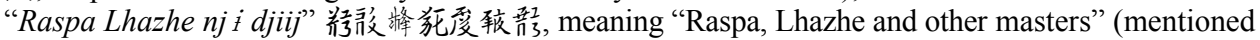

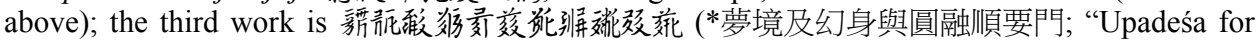
attaining unity between the dream of objects and illusory bodies"); transmission lineage includes: Lawapa (lja wa pja 淩瓶槥), who "truly accomplished this upadeśa", transmitted it to Tilopa, then to Nāropa, to Marpa, to *Mitshongpo (mjij tshcow po 唍落效, probably one of Marpa's disciples Mes tson pa Bsod nams Rgyal mtshan, see Blue Annals, p. 228), who again "truly accomplished 


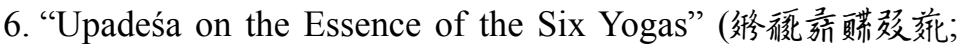
六法自體要門), transmitted by Nāropa and translated by Huizhao.

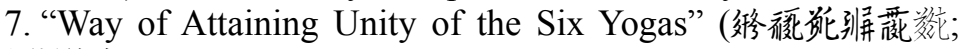
六法圓融道次), “collected by Yarlungs pa”.

Strictly put, the identity between Li Huizhao and Huizhao the translator from The Monastery of Manifestation of the Five Wisdoms is definite, whereas the personality of $\mathrm{Ti}$ ' $\mathrm{u}$ Huizhao remains obscure. However, while there is no evidence to the contrary, I suggest identifying these three persons. This identification further allows several observations on the nature of the transmission of Tibetan doctrinal literature, $B k a$ 'gdams textual repertoire and Atiśa's texts in particular: as the translator Huizhao was associated with The Monastery of Manifestation of the Five Wisdoms, where he was responsible for the transmission and translation of the texts belonging to both Bka' brgyud textual corpus and the doctrinal and ritual literature, i.e. the texts belonging to the Prajñāpāramitā tradition and doctrinal compositions of Sāntideva. Apparently this textual category included the Tangut versions of the Tibetan Mādhyamaka texts, and the Bka'gdams repertoire.

This allows the conclusion that The Monastery of Manifestation of the Five Wisdoms was a Buddhist centre which maintained a combination of Bka'gdams/ Bka' rgyud traditions; Huizhao was one of the representatives of this specific lineage. Thus, the discovery of the Tibetan versions of the Bka' gdams order in the vicinity of KharaKhoto as reported by Kano coincides with the overall dynamics of Buddhism in the area; this observation corroborates the indications of the high stature of Bka' gdams monks in Xixia. The period when this tradition was dominating this area might be roughly determined as 1160 s to 1220 s, that is the final demise of the Tangut Empire. This makes Tangut sources very close to Atiśa's period and simultaneous with the activities of the third generations of his disciples. The combination between $B k a$ ' rgyud and Bka' gdams is in tune with the mainstream of Bka' rgyud development in Tibet proper: the doctrinal discourse of both Gampopa and his four disciples was informed and took shape under the influence of Bka' gdams ideas (Davidson 2008, pp. 288-290).

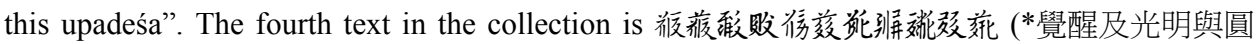
融順要門; “Upadeśa on attainment of union between awakening and light"), attributed to Nāropa; the fifth and sixth texts do not have clearly identifiable titles, but should relate to 'pho ba grong 'jug (transfer of consciousness) and bardo (intermediate existence) yogas respectively; however, more specific research is needed. The texts are defined as "collected" by Milarepa (mji zji lja rjar

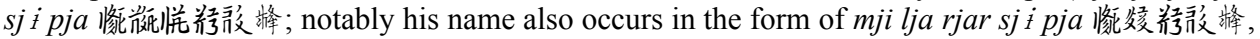
i.e. direct transcription of "Milaraspa"). The last of the compilations preserves the lineage of transmission which reads as follows: Tilopa, Nāropa, Marpa, from him the teaching was transmitted to Nge 彯, “*E,” i.e. Rngog Chos kyi rdo rje (1036-1102), one of the first generation of Marpa's disciples (see Blue Annals, p. 227). From these two teachers the instructions were transmitted to

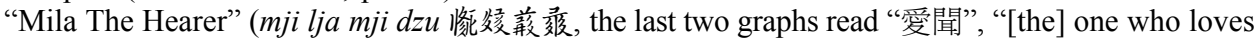
to hear").
} 


\section{Brief Introduction of Dīpamkara Texts in Tangut}

What follows is a more detailed introduction to the commentaries to Atiśa's works which have been identified so far. I provide a brief summary of the texts without any profound discussion on their intellectual contents. Also, I will currently omit the work by Rngog lotsāwa, since the part of the text available is written in cursive script, the scroll has disintegrated and the sequence of parts needs to be reconstructed before any actual study becomes possible.

\section{Inventory 868}

As mentioned above, this text is a fragment of a commentary to the text of Bden $b a$

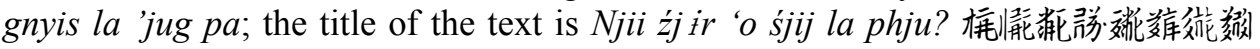
(*人二諦論記卷上; Tibetan title might be provisionally reconstructed as *Bden $b a$ gnyis la 'jug pa'i bkral or bkral 'grel). The extant part of the text covers fragments of the first juan (implying that at least there should have been one more chapter; judging from the degree of meticulousness of the discussion in the text, my impression is that the text originally included no less than 10 chapters) and bears editorial mark, indicating that the text was checked against the original and the copy was accepted as correct. Although the text is written in cursive script, it is generally legible. The text is not exactly a line by line commentary, but presents a more generalised discussion interwoven with the questions and answers concerning the nature of the discussed topics, which qualifies for the Sinitic genre of "notes" ( $j i$ 記). The surviving text part begins fairly close to the opening lines of the Tibetan text:

Sangs rgyas rnams kyis chos bstan pa/ bden pa gnyis la yang dag brten/

'Jig rten kun rdzob bden pa dang/ de bshin don dam bden pa' ${ }^{21}$

The first two lines of the Tangut text are slightly damaged (they contain discussion on the distribution of the Four Noble Truths among the categories of the conven-

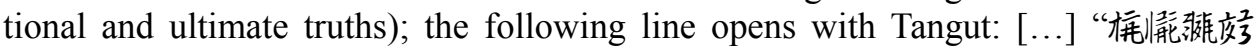

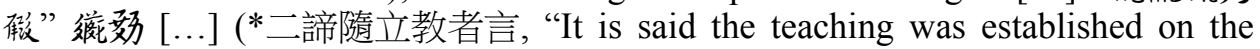
basis of the two truths"), which is translation of the Tibetan line "bden pa gnyis la yang dag brten" from the first śloka of Atiśa's treatise. The rest of the text is devoted to the discussion of the relationship between the two truths in the form of questions and answers. What follows is a paraphrase of the extant part.

The text opens with the exposition of the relationship between the two truths

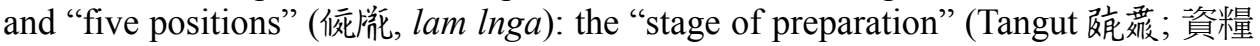
位, tshogs kyi lam) and “stage of exhortation” (Tangut 数数; 加行, sbyor ba’ lam) are attained in the realm of the conventional truth, whereas the attainment of the “stage of no-learning” (Tangut: 效经; 無學, mi slob pa'i lam) is associated with the

${ }^{21}$ Tibetan transcription used here and below is based on the version prepared by Liu Guowei for the publication of the original of the Tangut translation of Bden pa gnyis la 'jug pa.

Acta Orient. Hung. 69, 2016 
realm of the ultimate truth and the Noble Truth of cessation (the stages of "seeing the Path” (見道) and “following the Path” (修道) are missing). The names of the two truths are explained through their different applications: the one which covers the worldly affairs is "conventional", whereas the "ultimate reality" is defined as the "ultimate truth". The conventional truth is defined as such because it covers such aspects of reality as "birth and extinction", “destruction"; it “covers" (conceals, phoo 䔞, 蓋) the ultimate truth, etc. Further the text discusses the question of how then one should understand the worldly career of the Buddha who left his palace, engaged in ascetic practices and attained enlightenment at Vajrāsana; then transmitted the true Dharma

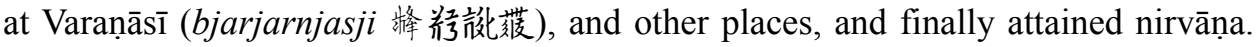
The answer is such that although the body of the Buddha is not subject to birth and extinction, he, as the guide of the sentient beings, has demonstrated the signs of birth and extinction of his "body of transformation". Although the body of transformation is substantially no different from the "Dharma body", and as such is not contained in the mundane world, it was revealed as subject to birth and death in order to guide sentient beings in the world of destruction and evil. This does not mean that after Buddha's nirvāna, the truth of his teaching also became concealed by the world, since the Dharma which he left behind remains in the domain of the ultimate truth.

The text further explores the definitions and characteristics of the ultimate truth. The set of definitions is fourfold: the ultimate truth is "not born and does not come to extinction” (Tangut: 数经妾经; 無生無滅; skye ba med pa dang 'gag pa med pa) and is not covered by “four characteristics” (组韽; 四相, rnam pa bzhi, “birth, growth, abiding and destruction"). The second set of characteristics is that the ultimate truth

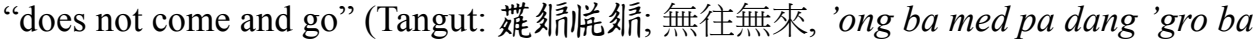
med $p a$ ), and is not covered by "three time periods". The third set of characteristics is

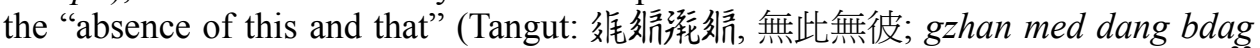

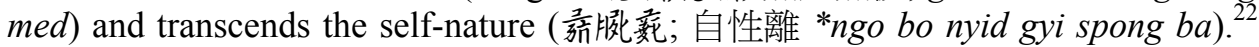
The fourth group of definitions indicates that the ultimate truth experiences no attainment and no loss (辞琂不级琂, 無得無失; thob pa med dang rgud pa med) and does

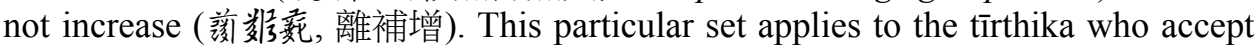
the existence of self, followers of Hinnayāna who accept reality of dharmas: both of these concepts "increase" the dharmatā which is erroneous. The text further engages in discussion of how "conventional" still can be called "truth": the reason for that is seen in its transformation into a real object (咙, 實境), which follows “realisation” by a Sage; and thus applies for pedagogical purposes as well. Thus, the term "truth" is applicable to both concepts, whereas their "conventional" and "ultimate" nature is

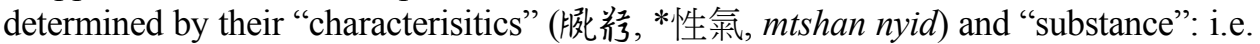
"conventional" applies to what emerges and perishes, whereas "ultimate" applies to what is not born and does not come to extinction. However, this does not imply onto-

${ }^{22}$ As far as I can tell, this is a Sinitic term, attested in the Chan Buddhist compilation, e.g. in the Tangut translation of the Recorded Sayings of Nanyang Huizhong. This term means that oppositions, afflictions etc., are devoid of self-nature and therefore disappear by themselves. Explanation in the Tangut text seems to corroborate the above translation. 
logical difference between the two, just as fire and water are different in substance; their self-nature is the same.

The relation between the two truths is further elucidated by the use of the so called “six phrases" (Tangut 橉钐, 六句, tshig drug): “not one and not different"

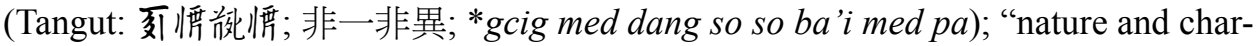
acteristics”(服跤䶊; 性及相, *ngo bo nyid dang mtshan nyid pa); “demonstrating

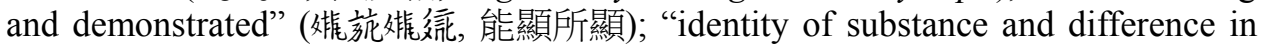

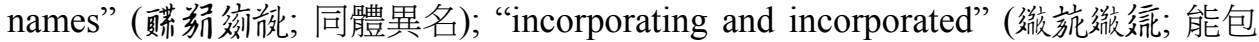

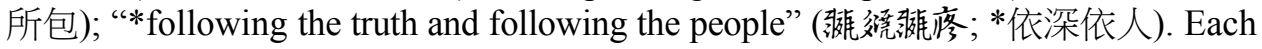
of these pairs of oppositions is explained through comparisons; while the conclusion is that through these pairs one can see mutual incorporation of the conventional and the ultimate.

The commentary further addresses the first line in the second śloka of Atiśa's original text: kun rdzob rnam pa gnyis su 'dod/log pa dang ni yang dag go/; for

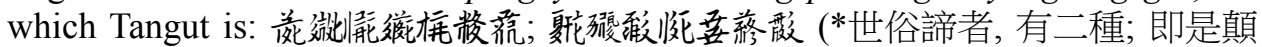
倒以及真實; “as for the conventional truth, it is of two kinds: one is perverted and [the other one] which is correct"). The commentary continues explaining the difference between the correct understanding and misconception, and refers to the metaphor of "the moon in the water", which appears in the next line of the source text. The question which follows the explanation refers to the two types of perverted "conventional

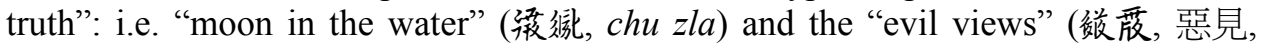
corresponds with "ngan pa" of the original; the following part of the commentary explains in more detail the classification of wrong views, i.e. altogether seven types of misconceptions) and the value of the correct application of the "conventional truth". Failure to adequately appreciate and analyse the "conventional truth" is the reason why the followers of heretical teachings together with śrāvaka are unable to arrive at a correct understanding of the Middle Way.

The first part of the relevant passage is devoted to a detailed description and analysis of "the moon in the water" type of misconceptions; while the "evil views" are mentioned somewhat in passing. In the discussion the author of the commentary

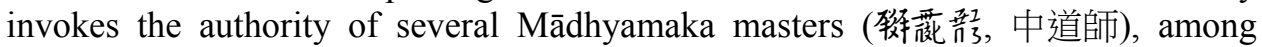
whom I was currently able to identify Kamalaśīla (740-795; kja mja lja sji lja 度晦

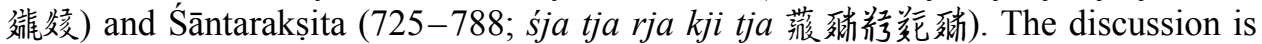
lengthy and certainly invites further study; it is a very detailed exposition of Atiśa's treatise: the extant part of the Tangut commentary covers only the first four ślokas of the original text.

The only example of a sūtra quotation in the text is marked as originating from the Lotus sūtra (娾商了, 華清, i.e. Tangut version of the Sinitic title Lianhua 蓮華), and Avatamsaka sūtra (娾效, i.e. Tangut version of the Sinitic title Huayan 華嚴) and

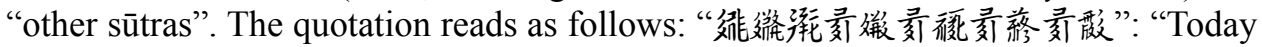
this body of mine is permanent body, Dharma body, True Body” (我今此身是常身, 法身, 真身). This sentence originates neither from the Avatamsaka nor from the Lotus, but is closely related to a quotation from Nirvāna sūtra discussed by Chengguan (澄 觀, 737-838) in his commentary to the Avatamsaka, which was widely circulating in 
Xixia. ${ }^{23}$ Considering the otherwise noticeable influence of Huayan doctrine on Tangut Buddhism, one can risk a suggestion that this commentary to the Satyadvayâvatâra was composed in Xixia on the basis of locally available knowledge of Buddhism and contemporaneous Buddhist vocabulary.

\section{Inventory 869}

As mentioned above, this text has no clearly identifiable title. The currently available scroll contains fragment of a commentary to the Bden ba gnyis la 'jug pa combined with a dhāran̄i text, added by a different scribe. The text is completed with a verse and editorial remark "end", no title, no information on the author and/or translator is provided. The opening part of the scroll is missing, first leaves are slightly damaged. The text is written in cursive script, but generally legible. Similarly to the previous composition, the commentary combines the original text with a traditional "question-

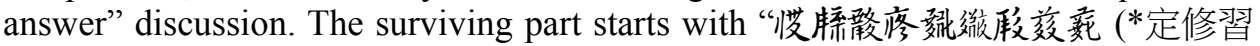
者乃至是離與障; from “the yogic practitioner” up to “transcending obstacles”), which corresponds with "rnal 'byor pa yis de rtogs na/ nyon mongs shes bya'i sgrib pa spongs" "'if the one who studies perfection and meditation understands this, [he will] transcend the kleśas and obstacles of knowledge (jñeyāvarana)". As one would

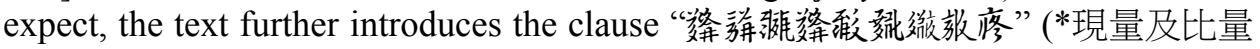
乃至愚人; from “the direct perception and inference” to "the stupid person", which corresponds to "mngon sum dang ni rjes su dpag/ sangs rgyas yis de gnyis gzung (bzung)/ gnyis pos stong nyid rtogs so zhes/ tshu rol mthong pa'i rmongs pa smra") etc. This paragraph contains specific discussion on the identity of the "fools with biased views", mentioned in Atiśa's text. According to the Tangut commentary, this derogation refers to śrāvaka and tīrthika, which are addressed in the following pas-

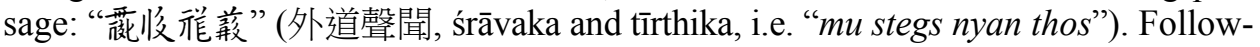

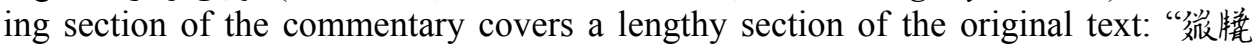

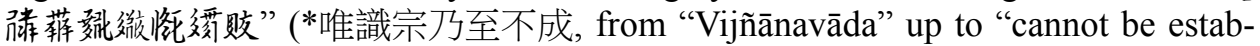
lished"; this corresponds to the paragraph starting with "rnam rigs pa" up to "[mang po nyid] du mi 'gyur ram") of Atiśa's text. The next part covers the part of the origi-

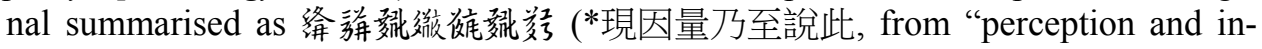
ference" up to "say so"; corresponding with the Tibetan original from "mngon sum rjes dbag dgos pa med/ mkhas pa rnams gyis byas pa yin"). The commentary further proceeds in compliance with the structure of the original: the next line is summarised

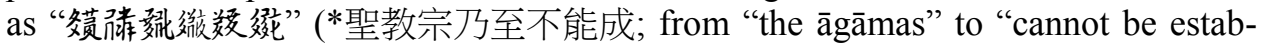
lished", which corresponds with the part of Tibetan text from "lung las kyang ni gsal po ru/ shes pa gnyis gyis mi rtogs shes"), followed by a brief entry on Bhavya (Tangut:

${ }^{23}$ For example, Da Fangguang Fo Huayan jing suishu yanyi chao, 大方廣佛華嚴經隨疏 演義鈔; T. 36, \#1836, p. 67a24: 吾今此身即是常身法身, 金剛不壞之身. The Tangut text substitutes jingang buhuai 金剛不壞 (Unbreakable vajra) with zhen 真 (true). Suo Luoning, "Xixia Fojiao xitong xing chu tan" discusses the matters of Huayan popularity in Xixia. 


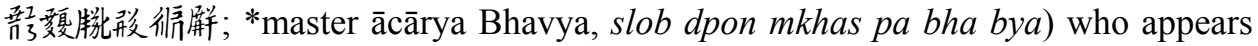
in the following line.

In this manner, the commentary arrives at the śloka which discusses Nāgārjuna (锥当, 龍樹, klu sgrob) and his student Candrakīti (婉效翣, 月名稱, zla grags). Here the commentary explicates various versions of Buddha's prophecy concerning Nāgārjuna restoring the true Dharma after Buddha's nirvāṇa; there are also quotations from unspecified sūtras concerning the decline of the Dharma. This is a lengthy paragraph, which warrants independent study; for the moment it will suffice to say that the Tangut version of Nāgārjuna's biography contains clear esoteric overtones, including the record of his interactions with ḍakin̄īs, visit to the Heavenly Palace etc. The text postulates that Candrakīrti received direct transmission of the teaching of the Middle Way from Nāgārjuna. In order to support the claim that the two truths are transmitted without interruption in the upadeśas of many masters, the Tangut commentary provides a list of transmission of the Madhyamaka teaching, which has to be discussed separately. ${ }^{24}$

After this lengthy biographical entry the commentary embarks onto the mainstream of Atiśa's work. The next paragraph in the commentary is devoted to the ex-

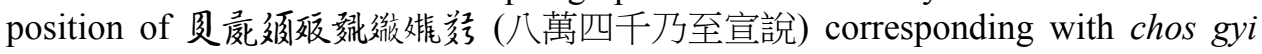
phung po brgyad khri dang/ bzhi stong gsungs ba thams cad ni of the original text. The next śloka is divided into two parts: the discussion on understanding emptiness and its relation to other forms of practice are discussed separately. The commentary continues, strictly following the sequence of the currently available Tangut translation of Satyadvayāvatara. Proceeding in this manner, the commentary eventually arrives

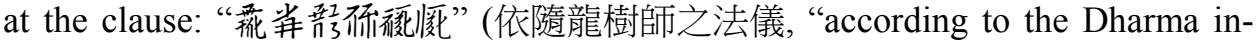
structions of Nāgārjuna"), which corresponds with the Tibetan klu sgrub lugs kyi... The author of the commentary further remarks, that the author of the sāstra (滋络, 論主) implies that although his understanding is insufficient for the exposition of the two truths, he does so relying on the tradition of Nāgārjuna and upadeśas preached by other famous masters. The Tangut commentary remarks in this respect that there

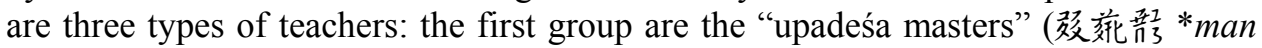

${ }^{24}$ The Tangut commentary presents the transmission of the truths in a form of a transmission of a tantric practice. The persons listed in the lineage are as follows: Nāgārjuna, Candrakīti,

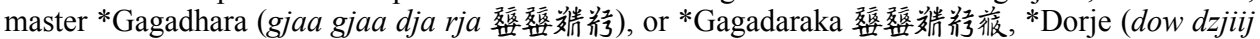

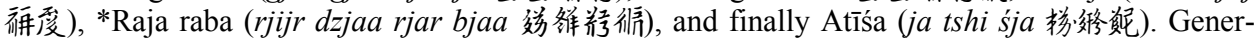
ally, the process of Atîsa's studies and scholarly achievements is well documented in both traditional sources and modern scholarship starting from the Eighty Verses composed by Nag tsho lotsāwa; accounts in the Blue Annals; account on Atîśa preserved in the 15th century bKa' gdams history Myriad Rays of the Sun by Lo dgon pa bsod nam lha'i dbang po (1423-1496; Bka' gdams chos 'byung rnam thar nyin mor byed pa'i 'od stong), studied and published by G. Venturi (2007); in $b K a$ ' gdams chos 'byung rnam thar also by Bsod nam lha'i dbang po etc. (see Elmer 1989, pp. 21-38) and other research on Atîśa by the same author. Although the "uninterrupted lineage of Madhyamaka masters" from Nāgārjuna to Atîśa is mentioned in the Eighty Verses, none of these names are identifiable in the list of Atīśa's teachers and masters as preserved in the text by Nag tsho or in the Blue Annals. *Raja raba can probably be identified as Dharmakīrti, under whom Atīśa studied for a long time. See also Chattopadhyaya (1996). However, no names of the masters mentioned in these sources qualify as the originals for the Tangut transcriptions. 


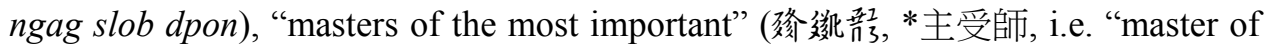

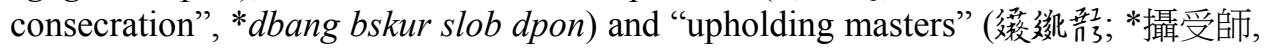
*yongs su gzung pa'i slob dpon). Out of these, the "upadeśa masters" are responsible for the initial familiarity with the teaching; the "masters of the most important" maintain disciples during their transition to the Great Path, in the same way as Asanga supported Vasubandhu; or [sic] Nāropa supported Tilopa etc. The third group includes the ones who follow the "path of siddhi" and guide the person in question. This discussion as well as Nāgārjuna's biography in the text deserves further study. ${ }^{25}$

After this discussion the text returns to the main body of the treatise and completes the commentary with a discussion of the circumstances of composition of Atiśa's treatise in Suvarnadvippa.

That is, inventory 869 is practically the full text of a commentary to the Satyadvayāvatāra, followed by a dhāraṇi text added to the text by another scribe, which appears to have no connection with the commentary to the Satyadvayāvatāra. As of now, proceeding from the considerations as presented above, it seems plausible that this text is a Tangut creation as well.

\section{Tang 198, inventory 833}

Unlike previous commentaries, the currently available copy of $N j \dot{t} \dot{t} d z$ ji ra o sjij mor

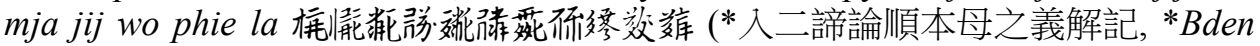
ba gnyis la 'jug pa'i bstan bcos don gsal) composed by *Byang chub seng ge is dated to 1178 . The scroll has disintegrated, therefore, the sequence of surviving pages is hard to determine. The spread shits of the text were combined together rather randomly, so the rearrangement of the text is complicated. The major problem is the nature of the text itself: it is not a line by line exposition, but rather a record of a discussion about various topics touched upon in Atiśa's text; that is, the source text is not introduced and explained line by line, but rather abbreviated to small compounds of two characters, or even introduced through the context. Longer quotations occur rarely. However, this text is the longest surviving Tangut commentary to Atiśa's treatise, demonstrating a high level of sophistication, and therefore is a valuable source for the study of the Tangut Buddhism. Below is a brief summary of what I have been able to extract so far, which by no means exhausts the contents of the text.

The text opens with an exposition of the story of Dipamkara's invitation to Tibet by Potj ij bji 效效技 (菩提光), i.e. Byang chub 'Od, who dispatched Njaa tsow

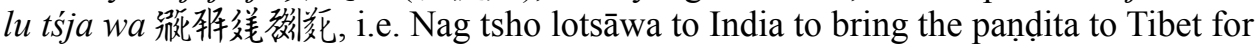
the benefit of the sentient beings. The text is not very clear, so I am going to provide a brief paraphrase of the opening part. According to the Tangut text, Nag tsho left for

${ }^{25}$ In fact one can go as far as to suggest the existence of the "Nāgārjuna lore" in the Tangut state: apart from an independent biography of Nāgārjuna, available in Tangut translation (Catalogue \#755, Tang 336, 807), there is a special biographical entry on him in the Commentary to the Ultimate Collection on the Great Seal, one of the most popular Tangut Mahāmudrā texts. 
India with a lavish gift of gold to meet with the pandita who was then the head of the monastic community (mjii dzju 茫终, 眾主) in Vikramaśīla (pji kja mja sji lja 犴

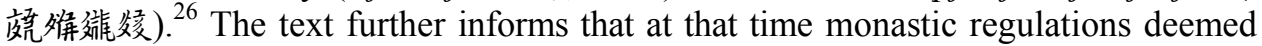
drinking wine to be a serious offense. However, a certain mendicant śramana violated this regulation; the other monks reported this to Dippamkara who afterwards expelled the śramana from the monastery, thus creating himself an "obstacle of speech". However, when Atiśa came to the śramana's dwelling he found no wine, but only milk. Thus his nature of a great yogi was revealed; therefore Dippamkara had to carry out a repentance ritual to relieve himself from the obstacles created by the unfair treatment. After a while, an ugly old beggar woman appeared while the monastic community was having a meal. After the meal, monks ascended on the pavilion, and threw down an object transcribed in the text as “thew tśju” 烸年请 (*duchu). ${ }^{27}$ Nothing of that fell into other people's hands, and the woman got it all. Atiśa watched the process from his door and recognised the old woman as a great yogini.

Afterwards, Atiśa offered a maṇala to this yoginī, requesting upadeśas and instructions three times. Yoginī then admonished Atiśa, saying that he does not have karmic connections with this place and time; even if she instructs him, this will be to no avail. She further advised that in order to resolve the obstacles, he should leave; otherwise it will be impossible for him to obtain Mahāmudrā in the present life time. Other than that, great benefit will be generated for the sentient beings and a lot of great disciples will appear thereby. Finally, the yoginī recommended that Atiśa should go to the Madhaydeśa of the Bod people. At this moment Nag tsho lotsāwa arrived at Vikramaśîla and entered into the negotiation with Dīpamkara after he found out he is the most prominent out of five hundred panditas. After paying homage to Vaj rāsana and other places, Atiśa finally arrived in Tibet due to the efforts of Byang chub 'Od.

The body of the commentary opens with a kind of table of contents indicating six topics around which the discussion revolves. These six categories constitute the hermeneutical framework adopted in the Commentary: (1) "of the origin of many ex-

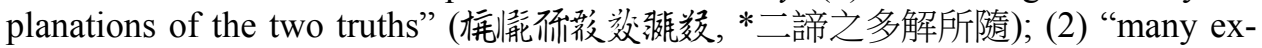
planations of the two truths” (梅羿研形效, *二諦之多解); (3) “self-substance of the

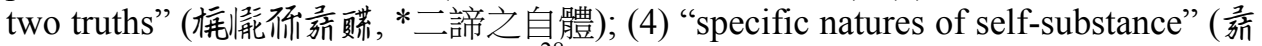

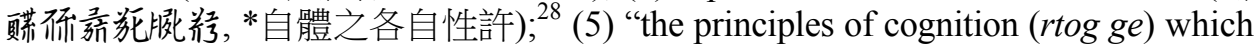

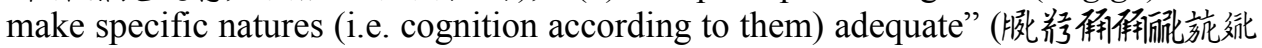
开莟, *性許畢竟令具正理); (6) “acquisition of the principles which thus were ascer-

${ }^{26}$ Atīśa's actual position in the Vikramaśîla monastic administration is subject for debate, summarised by Chattopadhyaya in his Atisis a and Tibet. The Blue Annals (pp. 146-147) mention him as the "steward of the monastic college", whereas the Russian version mentions him as "financial controller", while Atîśa speaks of himself as sthavira of the monastery. The Tangut texts mention that his position was that of the head of the monastic community.

${ }^{27}$ This paragraph is rather dubious, and my reading will require further clarification.

${ }^{28}$ This implies that although the substance of the two truths is identical, they have different implications in relationship to reality. 


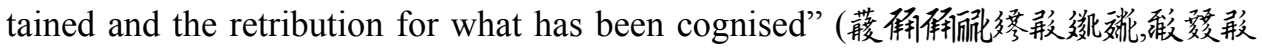
研落萭, *令智受畢竟理順及所知之果報). Each of these rubrics is independently discussed and defined, thus constituting the general structure of the text.

The range of topics discussed in this text reveals its proximity with inventory contained in 869. The text further discusses the etymology of "samvrtti" and "paramārtha"; the meanings of these terms in Sanskrit and in Tangut; the "identity" and "difference" in the substance between the conventional and ultimate truths, etc. Generally, the exposition follows the structure of Satyadvayāvatāra, beginning from the exposition of the two types of conventional truth (i.e. misconceptions and erroneous perception), followed by the discussion of the ultimate truth which does not have “dharma nature” (褯胧, 法性, chos nyid, dharmatā) and has no “subject” (褯很, 法持, chos can, dharmin); critique of the śrāvaka and tīrthika vehicles, adequacy of cognition through pramānas etc.; attaining the highest understanding of the true emptiness; the origin of the teaching in the doctrines and upadeśas of the illustrious masters of the past; necessity of analysis combined with faith and finally the circumstances of composition of the treatise. The text does not seem to contain specific entries on Nāgārjuna and Candrakīrti or any specific lineage of Madhyamaka transmission. However, the text features a fragment of polemics concerning the validity of cognition through inference and direct apprehension: the question is posed as to how one should understand the words of uselessness of pramāṇa, while such great masters as Dharmakīrti were very much in favour of cognition through pramānas.

Although the intellectual milieu of the text is intriguing in itself, there are some historical observations to be made on its basis: the account above demonstrates that the Tangut Buddhist circles were familiar with the Byang chub 'Od and Nag tsho lotsāwa lore; however, the version of the circumstances around Atiśa's arrival in Tibet known in Xixia did not deviate substantially from the Tibetan accounts: if I understand the relevant paragraph correctly, for his the journey to the Land of Snow he had personal implications in terms of liberation from the karmic obstacles, which he generated while trying to discipline a great yogi, disguised as śramana. ${ }^{29}$ The story of Atiśa expelling a great yogi from Vikramaśila reemerges in the text which is discussed below as well. Unlike Tibetan sources which indicate that the one expelled by Atiśa was in fact Maitripa, the Tangut texts are silent about the identity of the expelled yogi, they only preserve the indication on the story's connection with contemplation of Vajravārāhī.

${ }^{29}$ My knowledge of Atīśa's biography is based on the Eighty Verses by Nag tsho and the account form the Blue Annals. H. Elmer's (1977) Berichte über das Leben des Atīśa (Dīpaṃkaraśrijňāna) has remained unavailable to me. The matter of expulsion of a yogi from the monastery is recurrent in the Tibetan sources concerning Atīśa's decision to go to Tibet (see Tāranātha 1983, pp. 10-11; M. Tatz 1988, p. 478); the implications of this anecdote are discussed by Chattopadhyaya (1996, pp. 135-136 etc.). Various fragments concerning the matter of expulsion had been studied by H. Elmer (1979) in Rnam thar rgyas pa 2 pts etc. According to the majority of the accounts the one expelled from the monastery was Maitrīpa whose exact identity is, however, questionable. 


\section{Inventory Tang 215, \#871}

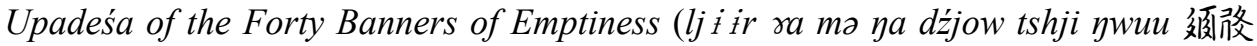
䊅薇数殿就; *四十種空幢要門). Although the text with this title does not appear among known works of Atiśa, the colophon to the Tangut translation unequivocally attributes this work to his authorship. A Tibetan title for this work is relatively easy to reconstruct as *stong nyid rgyal mtshan bzhi bcu 'i rnam pa'i man ngag; however, as of now I have not been able to identify the source version of this title. Contrary to other texts discussed above, this work is not a commentary to Satyadvayāvatära, but an independent composition attributed to Dīpamkara himself.

The text opens with an exposition of causes and conditions which resulted in the composition of this work, which is another version of the story narrated in the opening section of the text of Commentary 833 presented in the previous entry. The text is not very transparent, I would paraphrase it as follows: The great Indian master Dipankara was once a head of a monastic community in the Indian country of Ma-

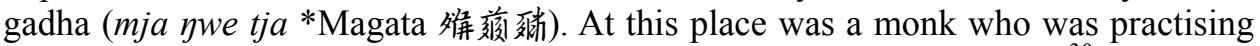
ritual of Vajravāāāī (Gju mja 礔㢁, 亥母) in an unconventional manner ${ }^{30}$ during the night, and was successful. The head monk, i.e. Dīpamkara, admonished him that although the ritual was a successful one, and both he and the monk are aware of that,

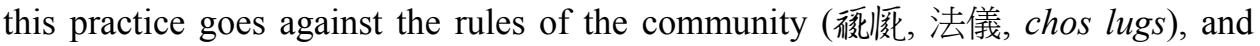
therefore should be discontinued. The śramana replied that he sees no problem with that, and if the community sees this practice as irregular, he can be expelled, which eventually happened. This situation was witnessed by an old woman; after the episode which generally repeats the one in the previous entry, Dīpamkara recognised her as a great yoginī, bowed to her feet and requested instructions. The woman refused by saying that she was only a stupid commoner; how could such a famous master pay her homage and imagine that she had upadeśas? However, Dīpamkara was persistent in his claim, and the woman finally revealed her true image of the goddess Tārā. Then Tārā continued instructing Dīpaṃkara in the manner similar with the one presented in the Commentary above, by saying that Dippamkara, although he is famous for his scholarship, will not be able to achieve anything in his present life; because of the karmic obstacles he created by expelling the monk, he would land in the Diamond hell. Then Tārā continued by saying: "Since you have seen my face, you are not going to collapse into hell, but nonetheless you should go to Tibet, greatly develop dhāranī and repentance rituals; thus you will purify your karma and generate benefit to the sentient beings of Tibet." After saying this, she was no longer seen. The text further continues with the lineage chart presented earlier in this paper, culminating in the figures of lotsāwa Sumpa and Wusheng (Skye med, Dehui).

${ }^{30}$ The Tangut text uses expression lha lhjwi 祘形, out of which lha is probably used phonetically to transcribe Tibetan $l$ ha, whereas the second, which occurs after a verbal prefix is used in its capacity of a verb "to take", "to seize", "to acquire"; thus the compound probably could mean-

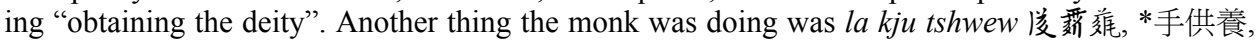
phyag mchod, a well attested general term for "prostration and worship". 
After this introduction, the body starts with the eulogy of "the mind of faith" (dźiej njiij 段徉, dad pa) and explains the six deficiencies resulting from the absence of faith and six benefits of developing thereof. Further text consists of forty key phrases which are elucidated in a brief commentary written in transparent language as a basic introduction to Buddhism. Although I was not able to identify the source, below I present a translation of a paragraph on the benefits of "having faith" (which is the third "banner") for a possible identification:

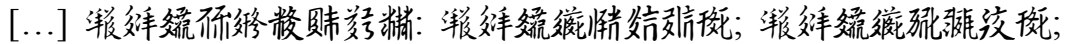

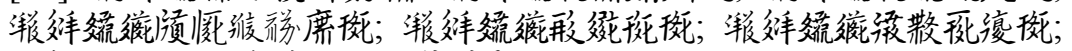

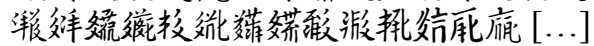

[...] The six merits of having faith are explained [as follows]: to have faith is like to have a good field; to have faith is like to have Cintāmaṇi; faith is like the king [who] brings in order the laws of his country; faith is like a fortress which is able to protect; faith is like a bridge over great water; faith is like the great merchant-supervisor and leads on the road (the last clause is tentative).

Passages like this constitute the body of the text. For the moment, I suggest that the key phrases can be extracted from the body of the text and be arranged into a composition in forty ślokas, which will thus account for the "Forty Banners of Emptiness". This text is by far the most interesting within the collection of Dīpamkara lore in Tangut, and deserves further study. In general, this paragraph might resemble the later $B k a$ 'gdams practices of teaching through parables and metaphors and is thus indicative of a broader accessibility of Bka'gdams teachings to the general public.

\section{Conclusion}

The purpose of this paper was to contextualise Dīpamkara's texts in the broader system of Tibetan Buddhism in the Tangut state. That is, the intention was to show that Tibetan Buddhism in Xixia was not a random collection of various esoteric practices and lineages. The Tangut version of Tibetan Buddhism emerged as a reproduction of the Bka' rgyud/ Bka'gdams intercourse, which was characteristic of Tibetan Buddhism during the 11 th -12 th centuries. The inquiry into the Tantric lineages preserved in the Tangut texts allowed identifying Mahāmudrā / Vajravārāhī / Six Yogas system as the major stems of Tibetan esoterism in Xixia. The holders of these traditions (Wusheng, Yarlungs pa, Sumpa, etc.) shaped the esoteric context of esoteric Buddhism in Xixia, and at the same time appeared in the capacity of the holders of Dipamkara's doctrinal heritage which was deemed indispensable for tantric progress. This especially concerns Wusheng (identified as the famous Tangut translator Dehui), lama translator Sumpa. Although no specific esoteric texts attributed to Atiśa have yet been discovered in Tangut translations, the Tangut esoteric master narrative \# 2825 features Dīpamkara in the same context as the most prominent Tangut esoteric masters, together with Milarepa and Tilopa, and places him generally within the tantric transmission 
lineage. Thus Dīpamkara becomes associated with the basic lineages of esoteric Buddhism in Xixia, which reflects an earlier view on his activities as an esoteric master. Considering the context in which Atiśa emerges in the Tangut texts, his association with Bka' rgyud denomination, at least among the Tangut Buddhists appears an established fact. This tendency resembles the major trend of combining Bka' rgyud esoteric systems with $B k a^{\prime}$ gdams discourse which was visible in Tibet in the works of Gampopa and his followers, as well as the absence of an opposition between esoteric and exoteric aspects of Buddhism in Xixia.

In the case of transmission of Dippamkara's teachings, the Tangut texts reveal remarkable coherence of places and persons: that is, the translators and holders of Dipamkara's teaching in Xixia were the same people who were also propagating both the Six Yogas and the Vajravārāhī system. One of the centres of such activity was the Samgharāma of the Manifestation of the Five Wisdoms, and one of the major persons responsible for upholding the lineage was translator monk Huizhao who translated both esoteric and exoteric compositions, particularly the texts by Śantideva. This observation confirms Bka' rgyud / Bka'gdams affiliation which once existed within the Tangut version of Tibetan Buddhism. This particular denomination formed one facet of Tangut Buddhism, but it probably was one of the most important dimensions of the Tibetan Buddhism in Xixia.

Atiśa's teaching in Xixia, from what it appears now, did not emerge as a simple replica of the Tibetan Bka'gdams: while the seminal Bka'gdams text of Bodhipathapradipa yet remains to be unidentified within the Tangut holdings in St. Petersburg and elsewhere, Tangut versions of a variety of Prajñāpāramitā texts combined with the Tangut translations of the works of Siantideva (especially Bodhicaryāvatāra and Sikșāsamuccaya) indicate that there was an effort to create an integrated system of Buddhist doctrinal learning rather than translating and transmitting all the available teachings and texts. The foundation for that system of doctrinal learning was the teaching of two truths presented in Satyadvayāvatāra, which generated substantial commentarial literature, parts of which might be identified as original Tangut compilations, whereas other works belong to the circle of the second and third generations of Atiśa's disciples in Tibet; Tangut composition Forty Banners of Emptiness as well as some other commentaries described above can also be considered an original Tangut work. Popularity of the Treatise of the Entry into the Two Truths in the Tangut state is in sharp contrast with the later Tibetan Bka'gdams repertoire which does not seem to add any special attention to this work of Atiśa and certainly places it much lower than Bodhipathapradipa. This observation allows inferring that the Tangut materials reflect an earlier stage of Bka' gdams development during which the Entry into the Two Truths remained an important text.

The time when Atiśa's teaching penetrated into Xixia cannot be established with certainty; however, the terminus ante quem is 1227 , that is, the demise of the Tangut state; some indirect evidence allows determining the period when Atiśa's works were definitely known in Xixia as early as the mid-12th century. All things considered, the period from the 1170 s to early-13th century seems to be the most plausible timeline for Atiśa's popularity in Xixia. Atiśa's influence in the Tangut state might be 
seen as another indication of the tendency to combine esoteric and exoteric Buddhism into a sort of a "perfect teaching" which carefully balances doctrinal and practical elements.

The above allows one to observe that despite doctrinal differences, Tibetan Buddhism in Xixia developed in a manner similar to Sinitic Buddhism: just as Sinitic Buddhism reproduced doctrinal and practical agenda of the Liao Buddhism and Huayan teaching of Northern China, Tibetan Buddhism in Xixia was based on the idea of reproducing a systematic whole of teaching traditions and meditative practices based on Bka' rgyud / Bka'gdams conglomerate.

\section{References}

Atīśa (2000): The Complete Works of Atīśa Śrī Dīpamikara Jñanna, Jo-bo-rje: The Lamp for the Path and commentary, together with the newly translated twenty-five key texts (Tibetan and English texts), translated and annotated by Richard Sherburne. New Delhi, Aditya Prakashan.

Blue Annals (2001): 'Gos lo tsa ba gZhon nu dpal [Гой лоцзава Шоннупэл]: Голубые аннальь [Blue annals]. St. Petersburg, Eurasia Press.

Catalogue $=$ Kychanov (1999)

Chattopadhyaya, Alaka (1996): Atiśa and Tibet. Delhi, Motilal Banarsidass.

Chen, Qingying 陳慶英 (2000): Xixia Dasheng Xuanmi Dishi de shengping 西夏大乘玄密帝師的 生平. Xizang Daxue Xuebao 西藏大學學報 No. 3, pp. 6-14.

Dasheng Yaodao Miji 大乘要道密集 (1983). Taibei, Micheng chubanshe.

Davidson, R. (2008): Tibetan Renaissance: Tantric Buddhism in the Rebirth of Tibetan Culture. Delhi, Motilal Banarsidass.

Dunnell, R. (2009): Translating History from Tangut Buddhist Texts. Asia Major Vol. 22, No. 1, pp. $4-78$.

Elmer, H. (1977): Berichte über das Leben des Atiśa (Dīpaṃkaraśrijñāna): eine Untersuchung der Quellen. Wiesbaden, Otto Harrasowitz Verlag.

Elmer, H. (1979): Rnam thar rgyas pa: Textmaterialien. Wiesbaden, Otto Harrasowitz Verlag (Asiatische Forschungen, Band 67).

Elmer, H. (1989): Nag Tsho Tshul khrims rgyal ba's Bstod pa rgyad cu pa in Its Extant Version. Bulletin of Tibetology 1, pp. 21-38.

English, E. (2002): Vajrayoginī: Her Visualizations, Rituals and Forms. Somerville, Wisdom Publications.

Hwang-cherng Gong 龔煌城 (2005): Xixia yuwen wenzi yanjiu lunji 西夏語文文字研究論集. Beijing, Minzu chubanshe.

Iuchi Maho (2006): Bka' gdams pa Manuscripts Discovered at Khara-khoto in the Stein Collection. In: Dotson, B.-Schetter-Schaub, C. A.-Takeuchi, T. (eds): Old and Classical Tibetan Studies: Proceedings of the 11th Seminar of the International Association for Tibetan Studies, Konigswinter, 2006. Halle, International Institute for Tibetan and Buddhist Studies.

Iuchi Maho (2012): A Note on the Relationship between the Bka' gdams pa School and Mi nyag/Xixia. Zangxue xuekan 藏學學刊 No. 8, pp. 58-62.

Kano Kazuo (2008): Rngog Blo Ldan Shes rab's Topical Outline of Ratnogotravibhāga Discovered at Khara-Khoto. In: Almogi, Orna (ed.): Contributions to Tibetan Buddhist Literature. PIATS 2006. Halle/Salle, IITBS, pp. 127-194. 
Kychanov, Е. І. (1999): Кычанов, Е. И.: Каталог тангутских буддийских памятников Института Востоковедения РАН [Catalogue of Tangut Buddhist texts from the collection of the Insitute of Oriental Studies, Russian Academy of Sciences]. Kyoto, University of Kyoto Press.

Kychanov E. I. (ed., transl.) (2013): Кычанов, Е. И.: Новые законы Тангутского государства. Первая четверть тринадиатого века [The new laws of the Tangut State: first quarter of the 13th century]. Moscow, GRVL.

Lü Cheng 呂溦 (n.y.): Hanzang Fojiao guanxi yanjiu shiliao 漢藏佛教關係研究史料. Sanche Publisher.

Martin, D. (2006): Padampa Sangye: A History of Representation of a South Indian Siddha in Tibet. In: Linrothe, Rob (ed.): Holy Madness: Portraits of Tantric Siddhas. New York, Rubin Museum of Art, pp. 108-123.

Masaaki Chikusa 竺沙雅章 (2000): Sō Gen Bukkyō bunkashi kenkyū 宋元佛教文化史研究. Tokyo, Kyūkoshoin.

Mathes, K. D. (2009): Maitrīpa's Amanasikāradhāra. A Justification of Becoming Mentally Disengaged. Journal of Nepal Research Center No. 13, pp. 5-32.

Nevskij, N. А. (1960): Невский, Н. А.: Тангутсукая филология [Tangut philology]. 2 vols. Moscow, GRVL.

Nie Hongyin 聶鴻音 (2012a): Xixia Fojiao shuyu de laiyuan 西夏佛教術語的來源. In: Xixia wenxian lungao 西夏文獻論稿. Shanghai, Shanghai guiji chubanshe, pp. 253-256.

Nie Hongyin 聶鴻音 (2012b): Tubo jingshi Xixia yiming kao 吐蕃經師西夏譯名考. In: Xixia wenxian lungao 西夏文獻論. Shanghai, Shanghai guiji chubanshe, pp. 257-258.

Nishida Tatsuo 西田龍雄 (1999): Seika go Buden mokuroku hensan jo no shomondai 西夏語佛典 目錄編纂上の諸問. In: Kychanov (1999), pp. xxxix-xl.

Shen Weirong 沈衛榮 (2006): Chonggou 11-14 shiji de Xiyu Fojiao shi-jiyu Ecang Heishuicheng Hanwen Fojiao wenshu de tantao 重構 11-14 世紀的西域佛教史一基於俄藏黑水城漢文 佛教文書的探討. Lishi yanjiu 歷史研究 No. 5, pp. 23-24.

Shen Weirong 沈衛榮 (2013): Wenben duikan yu lishi jiangou: Zangchuan Fojiao yu xiyu he zhongyuan chuanbo lishi yanjiu daolun 文本對勘與歷史建構: 藏傳佛教與於西域和中原 傳播歷史研究導論. Wenshi 文史 No. 4, pp. 43-93.

Solonin, K. (2012): The Teaching of Daoshen in Tangut Translation: The Mirror of Mind. In: Gimello, R.-Girard, Fr.-Hamar, I. (eds): Avatamsaka Buddhism in East Asia: Huayan, Kegon, Flower Ornament Buddhism. Origins and Adaptation of a Visual Culture. Wiesbaden, Harrassowitz Verlag, pp. 137-187.

Solonin, K. (2013a): Buddhist Connections between the Liao and Xixia: Preliminary Considerations. Journal of Song-Yuan Studies No. 43, pp. 171-219.

Solonin, K. (2013b): The "Prefect Teaching" and Liao Sources of Tangut Chan Buddhism: A Study of Jiexing Zhaoxin tu. Asia Major Vol. 26, No. 1, pp. 79-125.

Sperling, E. (1994): Rtsa-mi lo-tsā-ba Sangs-rgyas grags-pa and the Tangut Background to Early Tibetan-Mongol Relations. In: Kvaerne, P. (ed.): Tibetan Studies: Proceedings of the 6th Seminar of the IATS. Oslo, The Institute for Comparative Research in Human Culture, vol. 2, pp. 801-821.

Sperling, E. (2005): Further Remarks apropos of the 'Ba' rom pa and Tanguts. $A O H$ Vol. 57, No. 1, pp. 1-26.

Sun Bojun 孫伯君 (2010): Xixia xinyi fojing tuoluoni de duiyin yanjiu 西夏新譯佛經陀羅尼的對 音研究. Beijing, Zhongguo shehui kexue chubanshe.

Sun Bojun 孫伯君 (unpublished): Xixia wen Haimu erzhuan ji kaoshi 西夏文《亥母耳傳記》考 釋 (separate copy). 
Sun Bojun 孫伯君 (unpublished): Xixia Guoshi Fashizi kao 西夏國師發獅子考.

Sun Bojun 孫伯君 (forthcoming): Fa shizi Guoshi kao 西夏國師法獅子考. Forthcoming in Zhongguo Zangxue 中國藏學.

Suoluoning 索羅寧 (2012): Yixing Huijue jiqi Dafangguang Fo Huayan jing haiyin daochang shizhong xingyuan changpian lichan yi 一行慧覺及其《大方廣佛華嚴經海印道場十重行 願常徧禮懺儀》. Taida Foxue yanjiu 台大佛學研究 No. 23, pp. 1-78.

Suoluoning 索羅寧 (2013): Xixia wen Da shouyin wenxian zakao 西夏文大手印文獻雜考. In: Shen Weirong (2013), pp. 235-267.

Suoluoning 索羅寧 (2014): Xixia Fojiao zhi xitong xing chutan 西夏佛教之系統性初探. In: Shijie Zongjiao yanjiu 世界宗教研究 1, pp. 22-39.

Tāranātha (1983): Bka' babs bdun ldan. Seven Instruction Lineages. Translated by D. Templeman. Dharamsala, Library of Tibetan Works and Archives.

Tatz, M. (1987): The Life of the Siddha Philosopher Maitrīgupta. JAOS Vol. 107, No. 4, pp. 695701.

Tatz, M. (1988): Maitrīpa and Atiśa. Tibetan Studies Vol. 4, No. 2, pp. 477-478.

The Book of Kadam (2008): Core Texts. Translated by Thupten Jinpa. Sommerville, Wisdom Publications.

van der Kuip, L. (1993): Jayānanda. A Twelfth Century Guoshi from Kashmir among the Tangut. $C A J$ Vol. 37, pp. 188-197.

Venturi, G. (2007): The bKa' gdams School of Tibetan Buddhism. PhD Thesis. London, SOAS.

Wang Song 王頌 (2003): Kegon Fugen gyogān shūshō gi' kōhon no chosha ni tsuite 華嚴普賢行 願修證儀 甲本の著者について. Indogaku bukkyō gaku kenkyū 103. 